\title{
Implementasi Pembelajaran Kontekstual pada Mata Pelajaran Fikih di MTsN 7 Kepung Kediri
}

\author{
Khafidhotun Nasikhah ${ }^{1}$, Badrus ${ }^{2}$ \\ ${ }_{1}^{1}{ }^{2}$ Institut Agama Islam Tribakti (IAIT)Kediri \\ ${ }^{1}$ khafidhotun.nasikhah@gmail.com, ${ }^{2}$ baruskdr@email.com
}

\begin{abstract}
This article discusses the implementation of contextual learning in fiqh subjects at MTsN 7 Kepung Kediri. This research is a qualitative research with a phenomenological approach that focuses on implementation, evaluation models, contextual learning outcomes in fiqh subjects. The results of the study, (1) The implementation of contextual learning in fiqh subjects was carried out in several stages, namely, constructing, inquiry, questionnaire, creating a learning community, modeling, reflection and authentic assessment; (2) The evaluation model uses the Stake's Countenance Model; (3) The learning outcomes of the study, namely, students can understand the principles of Islamic laws in detail regarding food and drink, and gain meaningful knowledge in fiqh learning, inculcate Islamic legal values such as the formation of spiritual values and skills, students can distinguish between halal and haram food and beverages, formed a strong learning motivation, become a student who is responsible, tolerant, and disciplined, and fosters honest, polite, and selfconfident.
\end{abstract}

Key Word: Contextual Learning, Fiqh Learning

\begin{abstract}
Abstrak
Artikel ini membahas implementasi pembelajaran kontekstual pada mata pelajaran fikih di MTsN 7 Kepung Kediri. Penelitian ini merupakan penelitian kualitatif dengan pendekatan fenomenologi yang memfokuskan pada pelaksanaan, model evaluasi, hasil belajar pembelajaran kontekstual mata pelajaran fikih. Hasil penelitian ini menemukan bahwa (1) Pelaksanaan pembelajaran kontekstual mata pelajaran fikih dilakukan dengan beberapa tahapan yaitu, mengonstruksi, inquiry, questioning, menciptakan komunitas belajar, modeling, reflection dan autentic assessment; (2) Model evaluasinya menggunakan Stake's Countenance Model (3) Hasil belajar pembelajarannya yaitu, siswa dapat memahami pokok hukum-hukum Islam secara terperinci mengenai makanan minuman halal haram dan memperoleh pengetahuan yang bermakna pada pembelajaran fikih, tertanamkan nilai-nilai hukum Islam seperti terbentuknya nilai spiritual dan keterampilan, siswa dapat membedakan kehalal haraman makanan minuman, terbentuk motivasi belajar yang kuat, menjadi pribadi siswa yang bertanggung jawab, toleran, dan disiplin, serta menumbuhkan jujur, santun, dan percaya diri.
\end{abstract}

Kata Kunci: Pembelajaran Kontekstual, Pembelajaran Fikih 


\section{Pendahuluan}

Ajaran agama Islam memiliki tiga pokok bahasan yang saling berkaitan, yaitu keimanan (akidah), keislaman (syari'ah), ihsan (akhlak). Namun jika diterapkan terhadap siswa, maka keislaman atau syari'ah didahulukan. Mengingat, ilmu syari'ah atau fikih merupakan ilmu yang berbicara tentang hukumhukum syar'i amali (praktis) yang penetapannya diupayakan melalui pemahaman yang mendalam terhadap dalil-dalilnya yang terperinci. ${ }^{1}$ Fikih hadir meluruskan hukum-hukum serta alat kemudahan untuk beribadah kepadaNya, khususnya pada fikih muamalah yang kaitannya dengan hablum minannas. Sehingga kehalal haraman mampu terpahamkan, bahkan terealisasikan dalam kehidupan sehari-hari.

Pelajaran fikih perlu dipertegas kembali, khususnya pada usia remaja awal atau setara dengan madrasah tsanawiyah, yakni 12-15 tahun. Mengingat, masa remaja merupakan periode penting di rentang kehidupan, bahkan menururt Hall, masa remaja merupakan masa "strum and drang"

${ }^{1}$ Koto, Alaidin, Ilmu Fikih Dan Ushul Fikih (Sebuah Pengantar) (Jakarta: PT Rajagrafindo Persada, 2009). (topan dan badai), masa penuh emosi dan adakalanya emosinya meledakledak upayanya, yang muncul karena adanya pertentangan nilai-nilai. Emosi yang menggebu-gebu ini adakalanya menyulitkan, baik bagi si remaja maupun bagi orang tua atau orang dewasa di sekitarnya. Namun emosi yang menggebu-gebu ini juga bermanfaat bagi remaja dalam menemukan identitas diri. Reaksi orang-orang disekitarnya akan menjadi pengalaman belajar bagi si remaja untuk menentukan tindakan apa yang kelak akan dilakukannya. ${ }^{2}$ Dengan masa pencarian identitas diri, maka jika adanya bekal bimbingan yang tepat, terutama ilmu syari'ah yang terarah diharapkan dalam perkembangan dan pertumbuhannya mampu menjadi insan kamil. Terlebih jika dihadapkan dalam berbagai bentuk permasalahan, sehingga mampu menyelesaikan sesuai dengan tuntunan Islam.

Proses pembelajaran akan mampu terlaksana dengan baik, jika pendidik mampu menciptakan suasana pembelajaran yang menyenangkan. Pelaksanaan strategi (Jakarta: PT. Rajagrafindo Persada, 2010). 
pembelajaran yang tepat mendukung hasil belajar yang maksimal. Berdasarkan pengalaman di lapangan, kini banyak guru yang beralih dari pembelajaran ekspositori ke pembelajaran kontekstual dengan pendekatan problem based learning. Pembelajaran ekspositori, secara tradisional, ceramah, kurang mampu membawa peserta didik pada pengalaman belajar yang matang. Pembelajaran kontekstual

(Contextual Teaching and Learning) atau biasa disingkat CTL adalah pembelajaran yang menekankan pada keterkaitan antara materi pembelajaran dengan dunia kehidupan nyata, sehingga peserta didik mampu menghubungkan dan menerapkan kompetensi hasil belajar dalam kehidupan sehari-hari. ${ }^{3}$

Adapun tujuan lain dari pembelajaran kontekstual yakni, untuk membekali peserta didik berupa pengetahuan dan kemampuan yang lebih realistis karena inti pembelajaran ini adalah untuk mendekatkan hal-hal yang teoritis ke

${ }^{3}$ Suryani,Nunuk and Agung,Leo, Strategi Belajar - Mengajar (Yogyakarta: Ombak, 2012).

4 Taniredja,Tukiran dkk, Model-Model praktis. Sehingga dalam pelaksanaan pembelajaran, metode ini diusahakan mampu menyerap pelajaran yang teraplikasi dalam situasi real. ${ }^{4}$ Dalam prosesnya pembelajaran berlangsung secara alamiah dalam bentuk kegiatan siswa bekerja. Siswa benar-benar dilatih dan dibiasakan berpikir secara kritis, bukan hanya menransfer pengetahuan dari guru ke siswa, melainkan melalui proses mengonstruk. Sehingga dalam kelas kontekstual, peserta didik dibina dari segi berpikir kritis (critical thinking), berpikir analitis (analitical thinking), dan berpikir memecahkan masalah (problem solving) untuk menumbuhkan pribadi yang mandiri dan produktif di era revolusi digital.

\section{Hasil penelitian Ibrahim} menyatakan bahwa, implementasi strategi pembelajaran kontekstual berdampak pada peningkatan kualitas pembelajaran Pendidikan Agama Islam, meningkatkan penghayatan peserta didik pada nilai-nilai agama, serta menumbuhkan karakter positif pada peserta didik. ${ }^{5}$

\footnotetext{
5 Henra Ibrahim, "Implementasi Strategi Pembelajaran Kontekstual Dalam Pembentukan Karakter Peserta Didik Di Smp Negeri 2 Pinrang," Al-Ishlah: Jurnal Pendidikan Islam 16, no. 1 (June 20, 2018):
} 
Lain lagi dengan penelitian Hasnidar yang menyimpulkan bahwa pembelajaran kontekstual memberikan nilai yang lebih tinggi dibandingkan dengan pembelajaran ekspositori pada mata pelajaran PKN siswa SMP Negeri 1 Ulaweng Bone. ${ }^{6}$ Sementara penelitian Budiarti dan kawan-kawan menyimpulkan bahwa, model pembelajaran kontekstual berpengaruh terhadap hasil belajar sejarah pada tahun pelajaran $2018 / 2019 .^{7}$

Dari beberapa penelitian di atas, penulis meneliti pada sasaran lain yang berbeda, yakni menfokuskan pada bidang mata pelajaran fikih. Hal yang menarik untuk diteliti adalah, ada sejumlah guru di MTsN 7 Kepung Kediri termasuk guru mata pelajaran fikih yang mengubah cara mengajarnya dari pola lama yang berupa ceramah dan tanya jawab menuju ke pembelajaran yang lebih nyata. Dengan kata lain mereka lebih sering menerapkan pembelajaran

74 , https://doi.org/10.35905/alishlah.v16i1.735. 6 Hasnidar Hasnidar, "Pengaruh Pembelajaran Kontekstual Terhadap Hasil Belajar Pkn Siswa Kelas Viii Smp Negeri 1 Ulaweng Kabupaten Bone," Edumaspul Jurnal Pendidikan 1 (February 28, 2018): 42-47,

https://doi.org/10.33487/edumaspul.v1i1.39. kontekstual, dengan berbagai pendekatan seperti inquiry, discovery dan lain-lain.

$$
\text { Dari aneka ragam }
$$

pembelajaran guru di atas, akhirnya dengan berbagai pertimbangan, penulis meneliti pembelajaran kontekstual yang khusus menggunakan pendekatan problem based learning. Untukitu tulisan ini akan menguraikan tentang bagaimana implementasi pembelajaran kontekstual mata pelajaran fikih di MTsN 7 Kepung Kediri.

\section{Metode Penelitian}

Metode yang digunakan dalam penelitian adalah penelitian kualitatif dengan pendekatan fenomenologi. Menurut Bogdan \& Biklen, penelitian kualitatif adalah salah satu prosedur penelitian yang menghasilkan data deskriptif dan ilmiah yang bertujuan untuk memahami suatu fenomena dalam konteks sosial secara alamiah dengan mengedepankan proses

${ }^{7}$ Erni Budiarti, Zidni Zidni, and Bambang Eka Saputra, "Pengaruh Model Pembelajaran Kontekstual Terhadap Hasil Belajar Sejarah Siswa Kelas X MA NW Lenek Lauq," Fajar Historia: Jurnal Ilmu Sejarah Dan Pendidikan 2, no. 2 (December 6, 2018): 142-54. 
interaksi komunikasi yang mendalam berupa ucapan atau tulisan dan perilaku orang orang yang diamati. ${ }^{8}$ Peneliti berasumsi setiap individu tidak pernah dapat terlepas dari lingkungan sosialnya beserta nilai dan norma yang berlaku, dan setiap perilaku yang dimunculkan oleh individu tersebut hampir selalu berurusan dengan nilai dan norma yang berlaku di lingkungan tersebut. ${ }^{9}$ Karena itu dalam penerapan pendekatan fenomenologi ini peneliti berupaya melukiskan ciri-ciri intrinsik fenomena-fenomena itu sendiri. Dalam hal ini peneliti bertolak dari subjek (manusia) serta kesadarannya dan berupaya untuk mencari kembali kepada "kesadaran murni". dari pengalaman serta gambaran kehidupan sehari-hari dalam pelaksanaan penelitian. Di samping itu fokus penelitian ini juga menggunakan pendekatan filosofis, dan sosiologis. ${ }^{10}$ Pada intinya metode fenomenologi yang peneliti terapkan melihat segala sesuatu yang belum terselesaikan, khususnya di MTsN 7 Kepung Kediri:

Informan dalam penelitian ini pimpinan sekolah, guru mata pelajaran fikih, dan beberapa siswa. Sedangkan untuk metode pengumpulan datanya peneliti wawancara dengan guru, melihat praktek pembelajaran di kelas dan melihat dokumen-dokumen pembelajaran yang dibuat. ${ }^{11}$

Selanjutnya data yang telah terkumpul dianalisis secara detail, dengan mereduksi data, display data dan verifikasi. Dalam mengecek akurasi data dilakukan trianggulasi data. Yakni pendekatan multimetode yang dilakukan peneliti pada saat mengumpulkan dan menganalisis data. Ide dasarnya adalah bahwa fenomena yang diteliti dapat dipahami dengan baik sehingga diperoleh kebenaran tingkat tinggi jika didekati dari berbagai sudut pandang.

\footnotetext{
${ }^{10}$ Edgar, Andrew and Sedgwick, Peter, Key Concept in Cultural Theory (London and New York: Routlrdge, n.d.).

${ }^{11}$ Lexy J. Moleong, Metodologi Penelitian Kualitatif.
}

\footnotetext{
${ }^{8}$ Bogdan and S. Biklen, Qualitatif Research for Education (Boston: Allyn And Bacon, 1992).

${ }^{9}$ Lexy J. Moleong, Metodologi Penelitian Kualitatif (Bandung: PT Remaja Rosdakarya, 2000).
} 


\section{Hasil Penelitian dan Pembahasan}

\section{Pelaksanaan Pembelajaran}

\section{Kontekstual Mata Pelajaran Fikih di MTsN 7 Kepung Kediri}

Pelaksanaan pembelajaran kontekstual mata pelajaran fikih di MTsN 7 Kepung Kediri memiliki banyak keunggulan di antaranya: menciptakan pemahaman sedikitdemi sedikit dari konteks terbatas melalui proses mengonstruk dalam pembelajaran fikih, siswa belajar menemukan makna sendiri (inquiry) dalam pembelajaran fikih, mendorong siswa untuk mengetahui sesuatu dengan bertanya (questioning) dalam pembelajaran fikih, menciptakan masyarakat belajar (learning community) pembelajaran fikih, siswa melakukan pemodelan dalam pembelajaran fikih, melakukan refleksi dalam pembelajaran fikih, menggunakan autentic assessment dalam pembelajaran fikih. Beberapa tahapan tersebut menjadikan kelas hidup, menyenangkan serta mudah menerima pemahaman. Adapun penjelasannya adalah sebagai berikut:

\section{Proses Konstruksi Pemahaman Bertahap dalam Pembelajaran Fikih}

Hasil penelitian tentang pemahaman sedikit-demi sedikit dari konteks terbatas melalui proses mengonstruk dalam pembelajaran fikih dilakukan dengan wawancara dan observasi yang menunjukkan bahwa guru menjadikan pengalaman untuk memberi arti atau makna pada pengetahuan sesuai dengan pengalamannya secara nyata. Dari pengalaman kehiduupan sehari-hari, kemudian mereka berusaha untuk mengonstruksi pemahamannya sendiri yang dibangun sendiri sedikitdemi sedikit, mengaitkan antara pengalaman yang lama dan baru, sehingga pemahaman siswa akan semakin menguat. Prosesnya dilakukan secara bertahap yaitu diawali skemata, asimilasi, akomodasi, dan equilibrasi.

Melalui proses pentahapan itu mereka akan memperoleh pengetahuan bermakna, yakni pengetahuan yang tidak hanya sebatas penguasaan materi saja yang terbukti hanya mampu mengingat jangka pendek. Adanya proses mengonstruk selain menghasilkan pemahaman yang kuat dan bermakna, juga mampu memotivasi siswa sehingga antusias dalam mengikuti pelajaran. Menurut 
observasi dan wawancara yang saya lakukan pada tanggal 30 April 2018 pukul 08.50 - 10.30, Pak Azmil mengawali pembelajaran dengan cara mengaitkan kegemaran dan pengalaman seusia mereka, misalnya makanan favorit dan yang saat ini menjadi trending topik, kemudian mengidentifikasi kandungan yang ada dalam makanan tersebut beserta cara pengolahannya yang secara tidak langsung berkenaan kehalal haraman aini dan sababi. Selain itu melalui hal tersebut akhirnya mereka tertarik dan mendapatkan pengetahuan yang luas, misalnya dalam mengidentifikasi makanan terdapat materi biologi.

Maka dapat dijelaskan langkah pembelajaran tersebut telah sesuai dengan pembelajaran konstruktivis, yakni berupa diawali dengan pengaktifan pengetahuan yang sudah ada, kemudian perolehan pengetahuan baru, pemahaman pengetahuan, menerapkan pengetahuan dan pengalaman yang diperoleh, dan diakhiri refleksi untuk mengontekstualisasi pengetahuan.

Siswa Belajar Menemukan Makna Sendiri (Inquiri) dalam Pembelajaran Fikih
Proses inquiry merupakan inti dari pembelajaran kontekstual di MTsN 7 Kepung Kediri, hal tersebut sama halnya dengan teori yang ada pada pembelajaran kontekstual. Karena dengan berinkuiri pengetahuan dan keterampilan yang diperoleh siswa bukan hanya sekedar hasil mengingat seperangkat faktafakta, tetapi hasil dari menemukan sendiri, yang mana diharapkan memperoleh pemahaman yang jauh lebih kuat dan bermakna.

Masih berdasarkan hasil observasi dan wawancara yang telah dilakukan peneliti menemukan bahwa Pak Azmil juga menerapkan inquiry, yang pada prosesnya diawali dengan mengonstruksi pengetahuan berupa menggambarkan makanan dan minuman yang boleh dikonsumsi dan dilarang, kemudian dilanjutkan dengan bertanya hingga akhirnya menemukan makna apa yang akan dipelajarinya.

Proses inquiry merupakan kelanjutan dari proses mengonstruk yang menjadikan anak berpikir kritis tentang apa yang hendak ia pelajari, proses penemuan yang mereka kaitkan langsung dengan pengalaman mereka masing-masing. Apabila 
digambarkan pada siklus ber-inquiry pembelajaran tersebut yaitu diawali observasi, kemudian dilanjutkan dengan bertanya, mengajukan dugaan, pengumpulan data, dan terakhir penyimpulan. Pembelajaran kontekstual dalam penerapannya guru hanya mengarahkan dan membimbing saja, untuk menemukan makna pembelajaran.

\section{Mendorong Siswa untuk}

$\begin{array}{lcr}\text { Mengetahui } & \begin{array}{c}\text { Sesuatu } \\ \text { Bertanya }\end{array} & \begin{array}{r}\text { dengan } \\ \text { (asking) }\end{array} \\ \text { dalam }\end{array}$

\section{Pembelajaran Fikih}

Adanya pengetahuan jika tidak digali maka tidak akan berkembang, untuk itu dalam rangka mengembangkan pemahaman dan gagasan siswa pada pembelajaran fikih, guru mengunakan teknik bertanya sebagai salah satu cara mendorong siswa untuk mengali pengetahuan tersebut. Dari hasil wawancara dan observasi yang saya dapatkan, dengan adanya guru mendorong siswa untuk bertanya maka anak akan aktif, terlatih mengolah bahasa, dan mendapatkan pengetahuan yang lebih luas. Misalnya, dengan bertanya mereka mendapatkan penjelasan yang lebih mengenai kehalalan makanan minuman menjadikan cerdas dan lembutnya hati, begitu juga dalam beretika makan minum yang salah dapat menyebabkan kerasnya hati. Untuk itu dengan bertanya maka akan terjadi perolehan informasi baru, pengecekan pemahaman siswa, mengonfirmasikan apa yang sudah diketahui dan mengarahkan perhatian pada aspek yang belum diketahui.

\section{Komunitas Belajar (Learning Community) Pembelajaran Fikih \\ Learning community} memiliki banyak manfaat karena di dalamnya siswa bisa memperoleh pemahaman lebih sempurna melalui sharing atau berbagi pengalaman dengan teman. Dengan sharing, siswa yang pandai mengajari yang lemah, dan yang tahu memberi tahu pada yang belum tahu, yang pasif menjadi turut aktif.

Pada suatu forum diskusi yang dibuat acak oleh Pak Azmil entah dari segi tempat duduk dan kemampuan. Hal ini dilakukan agar mereka bisa saling belajar, antara yang sudah bisa mengajari yang belum bisa, biar anak terlatik untuk tanggung jawab meskipun tugas 
diembankan pada banyak pihak, agar kerukunan lebih terjaga, serta pelajaran lebih enjoy atau tidak monoton.

Kegiatan saling belajar ini bisa terjadi apabila tidak ada pihak yang dominan dalam komunikasi, tidak ada pihak yang merasa segan untuk bertanya, tidak ada pihak yang menganggap paling tahu, semua pihak saling mendengarkan, ada yang saling berpendapat dan menanggapi, serta mendengarkan. Jadi keadaan kelas tetap berjalan kondusif.

\section{Siswa Melakukan Pemodelan dalam Pembelajaran Fikih}

Pemodelan pada dasarnya membahasakan gagasan yang dipikirkan, mendemonstrasikan bagaimana guru menginginkan para siswanya untuk belajar, dan melakukan apa yang guru inginkan agar siwa-siswanya melakukan. Seorang yang menjadi model tidak harus guru, bisa kita mencari orang yang ahli pada mata pelajaran fikih, misalnya ustadz, bahkan juga dari para siswa. Di MTsN 7 Kepung Kediri pemodelan dilakukan dengan mempresentasikan hasil diskusi mengenai permasalahan makanan halal haram.

Diharapkan dengan ada yang mempresentasikan maka persoalan yang dibahas dalam diskusi, maka siswa dapat mengikuti apa yang dimaksud guru, apa orientasi dari materi tersebut, dapat lebih mudah diterima pemahamannya, sehingga mereka tidak hanya paham dari materi saja.

\section{Melakukan Refleksi dalam Pembelajaran Fikih}

Refleksi merupakan bagian mengevaluasi dari apa yang telah kita pelajari atau diterima siswa. Refleksi merupakan respon terakhir dari kejadian atau pengetahuan yang diterima. Menurut hasil observasi dan wawancara yang dilakukan pada tanggal 23 April $08.50 \quad-10.30$ pembelajaran kontekstual fikih di MTsN 7 Kepung Kediri, Pak Azmil memberikan pertanyaan langsung tentang apa yang diperoleh pada pukul pelajaran tersebut, hal-hal apa saja yang perlu dicacat dalam pukul pelajaran tersebut, diskusi mengenai apa yang telah dipelajari hari tersebut, bagaimana kesan dan pesan pembelajaran hari tersebut. 
Dengan adanya refleksi, maka pengetahuan yang tengah di endapkan siswa, yakni dengan apa yang baru dipelajarinya sebagai struktur pengetahuan yang baru, yang merupakan pengayaan atau revisi pengetahuan sebelumnya akan terkaitkan. Kunci dari itu semua adalah, bagaimana pengetahuan itu mengendap di benak siswa. Siswa mencatat apa yang sudah dipelajari dan bagaimana merasakan ide-ide baru.

\section{Menggunakan Autentic Assessment dalam Pembelajaran Fikih}

Pembelajaran fikih pada saat penilaiannya menggunakan nyata atau autentic assessment. Penilaian yang mengevaluasi dari semua rangkaian proses pembelajaran atau secara holistik. Penilaian pembelajaran fikih di MTsN 7Kepung menggunakan proyek atau kegiatan dan laporannya dapat berupa PR, kuis, karya siswa, presentasi atau penampilan siswa, demonstrasi, laporan, jurnal, hasil tes tulis, dan karya tulis sebagai dasar penilaian.

$$
\text { Penilaian dilakukan dari }
$$

berbagi aspek, mulai dari kognitif, afektif dan psikomotorik. Dengan mengikuti setiap tahapan proses tahapan penbelajaran, berupa penilaian sikap, keterampilan, keaktifan, serta mampu menyelesaikan bentuk penilaian sumatif amupun formatif. Kemudian dari hasil penilain tersebut digunakan sebagai feedback, yaitu untuk keperluan pengayaan (enrichment) standart minimal telah tercapai atau mengulang (remedial) jika standar minimal belum tercapai.

\section{Model Evaluasi Pembelajaran}

\section{Kontekstual Mata Pelajaran Fikih di MTsN 7 Kepung Kediri}

Kegiatan pembelajaran perlu adanya evaluasi atau penilaian yang digunakan untuk mengukur seberapa maksimal hasil pembelajaran di dalam kelas dan perkembangan siswa. Pembelajaran kontekstual mata pelajaran fikih MTsN 7 Kepung Kediri hampir sama dengan bentuk evaluasi pembelajaran kontekstul lainnya, yakni dengan menggunakan autentic assessment. Mulai dari penilaian kognitif, afektif, dan psikomotorik dan secara keseluruhan dari setiap tahapan proses pembelajaran. 
Menurut akhir observasi dan wawancara pada tanggal tanggal 3 Mei 2018, di MTsN 7 Kepung Kediri pada pembelajaran kontekstual fikih menggunakan model evaluasi yang digunakan, berkesesuaian dengan evaluasi authentic assessment Stake's Countenance Model, yakni evaluasi yang dilakukan dengan dua bentuk yakni, deskriptif dan penilaian dengan tahapan-tahapan yang dilakukan Pak Azmil sebagai berikut: Pertama, tahap antecedents phasa yang dilakukan sebelum program diimplementasikan apakah ada kejadian yang dapat mempengaruhi program, Misalnya terdapat anak yang sikapnya kurang sopan di depan guru, terdapat anak yang belum memahami dan terampil praktik mengklasifikasikan makanan halal haram. Tahap kedua adalah, transaction phase, yaitu pelaksanaan program: terdapan kejadian apa saja selama program dilaksanakan, dan program tersebut telah berkesesuaian. Misalnya di kelas VIII c, program yang dibuat materinya belum bisa diterima siswa, namun ternyata anak-anak tetap sangat antusias mengikuti, maka pertemuan hari ini bisa lebih dari nilai yang saya harakan.

Tahap ketiga adalah outcomes phase, yaitu mengetahui akibat implementasi pada akhir program. Misalnya adanya peningkatan pada pertemuan bab halal haram. Model Stake akan dapat memberikan gambaran pelaksanaan program secara mendalam dan mendetail. Terlebih mengenai pelaksanaan dan hasil pembelajaran mata pelajaran fikih di MTsN 7 Kepung Kediri. Dalam penilaiannya bisa dilakukan dengan teknik-teknik dan memilih jenis autentic assessment yang tepat.

Teknik-teknik autentic assessment pembelajaran kontekstual mata pelajaran fikih di MTsN 7 Kepung Kediri:

1. Mengukuran langsung kemampuan dan keterampilan peserta didik yang berhubungan dengan hasil jangka panjang pendidikan, seperti menjadikan peserta didik terampil menerapkan pengetahuan pada kehidupan sehari-hari dengan dihadapkan berbagai permasalahan, dapat mengaitkan dalam kehidupan sehari-hari. 
2. Mengadakan penilaian atas tugastugas di setiap proses belajar yang memerlukan keterlibatan luas dan kinerja yang kompleks. Jadi tahapan mulai dari cara siswa mengonstruk, inkuiry, quistioning, learning community, modeling, merespon hasil diskusi atau pada waktu proses penyelesaian tugas guru benar-benar mencermati

3. Mengadakan analisis proses yang digunakan untuk menghasilkan respon peserta didik atas perolehan sikap, keterampilan, dan pengetahuan yang ada.

$$
\text { Prinsip-prinsip evaluasi }
$$
yang digunakan guru fikih MTsN 7 Kepung Kediri hampir sama dengan prinsip evaluasi guru yang lain, yaitu:

1. Prinsip totalitas, keseluruhan, atau komprehensif

Evaluasi hasil belajar harus dilakukan untuk menggambarkan perkembangan atau perubahan tingkah laku peserta didik secara holistik. Artinya, evaluasi mampu mengungkapkan aspek kognitif, afektif, dan psikomotor.

\section{Prinsip kesinambungan}

Evaluasi yang baik dilakukan secara teratur, berkesinambungan dari waktu ke waktu, terencana dan terjadwal. Evaluasi yang demikian akan menggambarkan perkembangan peserta didik dari waktu ke waktu. Seperti halnya pada BAB makanan halal haram yang diamati dari hasil pertemuan sebelum dan sesudahnya dikoreksi agar dapat diketahui perkembangan siswa.

\section{Prinsip Objektivitas}

Evaluasi yang baik harus terlepas dari kepentingan subjektif. Hasil evaluasi tersebut harus menggambarkan kondisi peserta didik secara objektif.

Adanya teknik-teknik dan prinsip yang harus dipegang seorang guru, merupakan tujuan evaluasi atau langkah untuk menghasilkan penilaian yang baik. Namun selain dua hal tersebut, gunakan jenis autentic assessment yang tepat sesuai materi dan kondisi yang ada, misalnya pada $\mathrm{BAB}$ materi halal dan haram di MTsN 7 Kepung Kediri menggunakan jenis penilaian kinerja, yaitu anak secara langsung diberi tugas untuk menyelesaikan beberapa permasalahan dalam kelompok. 
Penilaian pembelajaran kontekstual mata pelajaran fikih di MTsN 7 Kepung Kediri dilakukan dengan membentuk beberapa kelompok, membahas hukum makanan dan minuman halal haram. Penilaiannya menggunakan authentic assessment, sedangkan model evaluasi pembelajarannya menggunakan stake's countenance model, yakni dengan menggunakan matriks deskripsi dan matriks pertimbangan atau penilaian, yang dilakukan dengan beberapa tahapan. Tahapan-tahapan tersebut dapat dilihat dari hasil penelitian yang telah disingkronkan berdasarkan teori stake's countenance model sebagai berikut:

\section{Tahap antecedent}

Hal tersebut dapat diamati dengan siswa secara berkelompok melakukan perencanaan menyelesaikan permasalahan mengenai hukum makanan minuman halal haram.

a. Deskripsi matriks

$$
\text { Berdasarkan hasil observasi }
$$
terdapat 4 kelompok dari 8 kelompok yang rata-rata per kelompok berjumlah 4 orang menunjukkan kemampuan pengetahuan baik (B); pada penilaian diri dan penilaian antar teman menunjukkan perilaku sering, dengan pemberian masing-masing point 3 berupa: berdoa sebelum dan sesudah melakukan sesuatu, masuk kelas tepat waktu, kesediaan melakukan tugas sesuai kesepakatan. Dengan hal tersebut menunjukkan keantusiasan peserta didik mengikuti pembelajaran. Selain itu terdapat 4 kelompok dengan kemampuan pengetahuan cukup (C) yang ditunjukkan dengan belum menguasai pemahamannya mereka pada pertemuan sebelumnya tercerminkan berupa: siswa belum mampu merespon dengan sesuai pertanyaan dari guru, berupa penyebutan jenis kehalal keharaman yang tergambar pada penilaian diri dan antar teman pemberian masingmasing point 2 , berupa berbicara sendiri ketika berdoa sebelum dan sesudah melakukan sesuatu, apabila diberikan tugas mengeluh.

b. Penilaian matriks

Penilaian ini diambil dari dua sisi standar, yaitu penilaian kemampuan kognitif, skill mendapat point A (sangat baik), dan penilaian diri atau antar teman mendapat poin 4 (sering melakukan). Dari standar penilaian dan observasi dapat disimpulkan bahwa pada saat tahapan antecedent, sebagian siswa memiliki pengetahuan yang baik, dan terdapat sebagian siswa yang memiliki unsur penilaian diri, antar teman, sosial maupun keterampilan yang kurang baik.

\section{Tahap transaction}


Hal tersebut dapat diamati dengan siswa secara berkelompok melaksanakan proses menyelesaikan permasalahan mengenai hukum makanan minuman halal haram.

a. Deskripsi matriks

Berdasarkan hasil observasi terdapat 6 kelompok yang memiliki kemampuan pengetahuan baik (B) dan 2 kelompok memiliki pengetahuan cukup (C), hal tersebut ditunjukkan dalam proses pembelajaran di mana peserta didik dapat mengutarakan kejelasan sebab keharaman pada makanan melalui delapan pertanyaan yang dibagikan pada setiap kelompok, antara lain:

1) Bagaimana hukumnya ketika makan daging kera ketika berada didalam hutan belantara? (korban kecelakaan pesawat)

2) Bagaimana hukumnya makan daging ayam yang mati tertabrak motor? Alasannya?

3) Bagaimana hukumnya makan ikan yang ditangkap dengan cara diracun?

4) Bagaimana hukumnya ketika makan daging kera ketika berada didalam hutan belantara? (korban kecelakaan pesawat)

5) Bagaimana hukum makan burung yang ditembak? Alasannya?

6) Bagaimana hukum makan burung yang ditembak? Alasannya?
7) Bagaimana hukumnya makan ikan yang ditangkap dengan cara diracun?

8) Bagaimana hukumnya makan cicak? Alasannya?

Dari kedelapan pertanyaan tersebut mereka dapat menjelaskan satu per satu dan mempresentasikan di depan kelas, seperti halnya persolan keputusan keharaman cicak yang mereka ambil dari tahapan dalil yang dijelaskan oleh Pak Azmil Amin berasal dari beberapa hadis sebagai berikut:

"Cicak dan tokek belang adalah satu jenis, sedangkan tokek belang merupakan jenis cicak yang besar. Para ahli bahasa sepakat bahwa cicak merupakan binatang yang menyakiti. Nabi SAW memerintahkan dan menganjurkan untuk membunuhnya karena ia merupakan salah satu hewan yang bisa membuat sakit." Kemudian mereka serat lagi:

"Cicak tersebut terdapat zat yang dapat menimbulkan penyakit kusta." Yang dilanjutkan dengan hadits, "Rasulullah SAW memerintahkan untuk membunuh cicak. Beliau bersabda, 'Dahulu cicak ikut membantu meniup api Ibrahim AS." Dan pada akhirnya mereka memutuskan cicak haram, setelah melihat uraian hadis yang menjelaskan, bahwasanya: "Makanan minuman haram berasal dari binatang menjijikkan seperti tikus, lalat, dan ulat."

Selain mendapatkan pengetahuan yang baik, mulai dari mengidentifikasi, menjawab, mendemonstrasikan hasil diskusi dengan cara presentasi kehalal haraman, peserta didik juga turut andil 
dengan memberikan beberapa respon dengan menunjukkan keterampian dan pembawaan sikap sosial dan spiritual mereka. ${ }^{12}$ Hal ini ditunjukkan rata-rata 7 kelompok memiliki poin 3 atau sering dengan tercerminnya sikap aktif dalam bertanya, mengerjakan mengumpulkan tugas tepat waktu, menghargai pendapat teman, menggunakan bahasa santun; sedangkan terdapat 1 kelompok menunjukkan keterampian dan pembawaan sikap sosial dan spiritual mereka dengan rata-rata memiliki 2 poin. Hal ini tercermin pada kurang turut bekerja dalam kelompok, kurang menerima tugas yang diberikan guru, ricuh dalam penyampaian pendapat.

b. Penilaian matriks

Penilaian ini diambil dari dua sisi, yaitu penilaian kemampuan kognitif skill mendapat point A (sangat baik), dan penilaian diri atau antar teman mendapat poin 4 (sering melakukan). Dari standar penilaian tersebut dapat disimpulkan bahwa pada saat tahapan transaction hampir keseluruhan siswa telah memiliki kemampuan kognitif yang baik, namun tetap belum sebanding dengan perilaku spiritual, sosial dan keterampilan skill.

\section{Tahap outcomes}

Hal tersebut dapat diamati dengan siswa mampu menyelesaikan permasalahan terkait makanan dan minuman halal haram serta mampu mengaplikasikan atau mempraktikkan dalam kehidupan sehari-hari.

a. Deskripsi matriks

Berdasarkan hasil observasi, terdapat 1 kelompok yang memiliki nilai A (sangat baik), 6 kelompok memiliki nilai B (baik), dan 1 kelompok lainnya belum mampu mengidentifikasi sebab kehalal haraman makanan dan minuman yang berada pada persoalan "Bagaimana hukum makan daging ayam yang mati tertabrak motor? Berikan alasannya?"

Mereka menjawab bahwasanya hukum memakan ayam yang mati tertabrak motor itu diperbolehkan, padahal jika terdapat hewan yang mati tanpa disembelih dan menyebut nama Allah, maka diharamkan karena hal itu seperti halnya bangkai. Selain pada poin pengetahuan atau kogmitif skill juga terdapat penilaian dari segi sikap, sosial dan keterampilan yang mereka tunjukkan. Pada penilaian segi sikap, sosial dan keterampilan terdapat tujuh kelompok yang menunjukkan poin 3 atau sering dan satu kelompok menunjukkan poin 2 atau kadang-kadang. Perincian dari perilaku spiritual, sosial dan 
keterampilan berupa berdoa sebelum dan sesudah melakukan sesuatu, memberi salam sebelum dan sesudah menyampaikan pendapat, menjalankan ibadah tepat waktu, membaca Al Qur'an, tidak nyontek dalam mengerjakan ujian, mengakui kesalahan atau kekurangan yang dimiliki, mengumpulkan tugas tepat waktu, melaksanakan tugas individu dengan baik, menghargai pendapat teman, aktif dalam kerja kelompok, aktif dalam kegiatan pembelajaran di kelas.

b. Penilaian matriks

Penilaian ini diambil dari dua sisi, yaitu penilaian kemampuan kognitif skill mendapat poin A (sangat baik), dan penilaian diri atau antar teman mendapat poin 4 (sering melakukan). Dari standar penilaian tersebut dapat disimpulkan bahwa pada tahapan outcomes sebagian besar siswa memiliki kemampuan kognitif skill yang baik (B), namun hal tersebut masih belum maksimal dengan terdapatnya 1 kelompok yang belum dapat menyelesaikan permasalahan. Sedangkan pada perincian dari perilaku spiritual, sosial dan keterampilan cukup baik, hal ini ditunjukkan hanya terdapat satu kelompok yang mendapat poin kadang-kadang atau 2.

Hasil Belajar dalam Bentuk Pembelajaran Kontekstual Mata Pelajaran Fikih di MTsN 7 Kepung Kediri
Pembelajaran yang maksimal dan terarah membuat kelas hidup memiliki nilai keunggulan tersendiri. Semua tidak lepas dari strategi mengajar yang tepat peran guru inovatif dan kreatif. Serta penggunaan guru yang mampu membuat pembaharuan serta membuat siswanya terampil dan mampu memaknai pengetahuan yang dimiliki dan diterapkan dalam kehidupaan sehari-hari. Seperti halnya guru yang mengimplementasikan pembelajaran kontekstual mata pelajaran fikih di MTs Negeri 7 Kediri Kec. Kepung Kab. Kediri.

1. Siswa Dapat Memahami Hukum Pokok Islam Secara Terperinci Mengenai Makanan Minuman Halal Haram dan Memperoleh Pengetahuan yang Bermakna pada Pembelajaran Fikih

Pembelajaran kontekstual mata pelajaran fikih di MTs Negeri 7 Kediri memiliki hubungan pengetahuan yang bermakna, dalam artian antara bentuk pengetahuan yang diajarkan, langsung berkenaan dengan realitas di lapangan atau aktifitas sehari-hari. Sehingga siswa benarbenar tahu apa yang sedang dipelajari, fungsi, dan tujuan siswa belajar. Dengan mengetahui makna yang dipelajari, maka semakin mudah pula siswa menerapkan dalam kehidupan sehari-hari dan terampil dalam pengamalan fikih maupun pemecahan berbagai jangka panjang. Hal itu dibuktikan pula dengan perolehan nilai 
rata-rata yang meliputi ulangan harian, portofolio, penilaian harian, nilainya berada di atas KKM yaitu 79. Dimulai dari kelas mulai kelas VIII a memiliki rata-rata 88,2 kelas VIII b rata-ratanya 85, dan kelas VIII c rata-ratanya 85,5.

2. Dapat Tertanamkan Nilai-Nilai yang Ada dalam Hukum Islam Seperti Terbentuknya Nilai Spiritual dan Keterampilan

Untuk menjadi insan kamil, salah satunya yakni mengamalkan apa yang menjadi ajaran agama Islam. Hal tersebut akan terlatih, terlebih ketika mereka memiliki nilai spiritual dan keterampilan yang tinggi. Menurut hasil wawancara dan observasi di kelas VIII a, pada tanggal 30 April 2018, pukul 10.30 - 11.00. Bisa ditunjukkan dengan kehalal haraman makanan bagi anak-anak sangat menerima dan menghargai aturan Allah, dimulai dari menciptakan akhlakul karimah, dan penerapan penggunaan pola makan yang baik. Di sisi lain mereka juga terampil, selektif dalam pemilihan makanan yang baik. Mampu menyelesaikan berbagai tugas portofolio mengenai persoalan kehalal haraman. Hal ini dibuktikan dengan terbentuknya nilai sikap dan keterampilan dapat dibuktikan melalui hasil rata-rata nilai sikap dan keterampilan kelas VIII a, b, dan c rata-rata masingmasing mendapat poin 3 , yang berarti mereka sering menerapkannya.
3. Siswa dapat Membedakan Halal dan Haram Makanan Minuman

Dengan pembelajaran fikih yang tidak lepas dari hukum-hukum Islam, dan dikhususkan pada materi kehalal haraman makanan minuman memiliki cakupan yang cukup luas, ketika diterapkan dengan pembelajaran kontekstual, dalam artian tidak hanya mengenai kehalal haraman makan minuman, namun hal tersebut berpengaruh langsung pada perkara ibadah dan kesehatan. Hal tersebut dibuktikan pada kelas VIII a 8 kelompok mampu menjawab semuanya, kelas VIII b 6 kelompok mampu menjawabnya, VIII c 7 kelompok mampu menjawabnya, dengan masing-masing perkelas memiliki 8 kelompok, sedangkan perkelompok berjumlah 8 orang.

4. Terbentuk Motivasi Belajar yang Kuat Jika dilihat motivasi terdiri dari dua ranah internal dan eksternal. Namun dari dua motivasi tersebut, motivasi internal memberi dorongan paling kuat, yakni dorongan keinginan dari diri sendiri dengan pembelajaran kontekstual pada mata pelajaran fikih maka di situ motivasi diasah dari dalam, dari hubungan yang bermakna di setiap pengetahuan, hingga mereka sadar bahwa hal tersebut penting untuk dipelajari dan diamalkan.

Selain hubungan yang bermakna, adanya pembelajaran kontekstual MTsN 7 
Kepung Kediri juga dilalui dengan proses mengonstruk sehingga apa yang tertanam setiap penggalian, pemahaman, hingga penemuan pengetahuan akan semakin mengena. Hal itu dibuktikan dengan peniaian kinerja, dijelaskan rata-rata nilai anak kelas $\mathrm{C}$ adalah 90 dan paling rendah 85. Sedangkan nilai yang diperoleh kelas B rata-rata 90 dan paling rendah adalah 85 itupun hanya diperoleh satu anak saja. Kalau kelas A rata-rata adalah 90 dan paling rendah juga 90 .

5. Memiliki Pribadi yang Bertanggungjawab, Toleransi, dan Disiplin

Dalam pembelajaran kontekstual fikih MTsN 7 Kepung Kediri sangat detail dalam membina para siswa, hingga muncullah pribadi yang bertanggung jawab. Menurut hasil Observasi di kelas VIII b, pada tanggal 24 April 2018, pukul 08.50 - 09.00, pribadi bertanggung jawab dalam fikih dilatih melalui senantiasa memberikan mereka penguatan atas pekerjaan yang dilaksanakan secara berkelompok atau individu. Rasa toleransi muncul pada saat mereka belajar menghargai satu sama lain dari segi kemampuan maupun beberapa pendapat antara pendapat yang bisa diterima atau tidak. Kedisiplinan muncul dengan mereka selalu berlatih mengerjakan tepat waktu.

Adanya tugas jika siswa belum bisa memaknai apa yang ia kerjakan, maka tugas tersebut akan menjadikan beban moral tersendiri. Terkadang marasa malas, penat, dan jenuh dengan aktifitas yang ada membuat pekerjaan berantakan. Namun, lain halnya pembelajaran kontekstual fikih di MTsN 7 Kepung Kediri. Hal tersebut bisa dibuktikan melalui pengamatan pada kolom penilaian sikap sosial yang bertanggung jawab, toleransi, dan disiplin. Dari ketiga kelas tersebut rata-rata mereka mendapatkan poin masing-masing 3, yaitu melakukan sikap bertanggung jawab, toleransi, dan disiplin.

6. Tumbuhnya Sifat Jujur, Santun, dan Percaya Diri

Pembelajaran kontekstual fikih di MTsN 7 Kepung Kediri dapat memunculkan jiwa jujur, santun, dan percaya diri melalui proses belajar kelompok. Tanpa diperintah, anak-anak itu sudah saling bertoleransi. Demikian pula sikap jujur, sebagian besar mencerminkan kejujuran, misalnya tidak nyontek dalam mengerjakan ujian. Demikian pula ketika melaporkan data mereka melakukan apa adanya, meskipun soal makanan dan minuman yang haram. Di sini nampak bahwa sikap berani, aktif dan kritis, telah meresap dalam kehidupan siswa. Hal tersebut bisa dilihat nilai rata-rata kejujuran, santun, dan percaya diri mereka masing-masing mendapat poin 3. 


\section{Kesimpulan}

Berdasarkan hasil analisis yang telah penulis lakukan, maka dapat diambil kesimpulan sebagai berikut:

1. Pelaksanaan pembelajaran kontekstual mata pelajaran fikih di MTsN 7 Kepung Kediri dilakukan dengan beberapa tahapan yaitu, Pemahaman sedikit-demi sedikit dari konteks terbatas melalui proses mengonstruk dalam pembelajaran fikih, siswa belajar menemukan makna sendiri (inquiry) dalam pembelajaran fikih, mendorong siswa untuk mengetahui sesuatu dengan bertanya dalam pembelajaran fikih, menciptakan masyarakat belajar (learning community) pembelajaran fikih, siswa melakukan pemodelan dalam pembelajaran fikih, melakukan berpikir kritis, aktif, dan kreatif dalam pembelajaran fikih, melakukan refleksi dalam pembelajaran fikih, menggunakan autentic assessment dalam pembelajaran fikih.

2. Model evaluasi pembelajaran kontekstual mata pelajaran fikih di MTsN 7 Kepung Kediri dilakukan dengan penggunaan model autentic assessment Stake's Countenance Model, yang diterapkan dengan tahapan berikut: Antecedents phase (tahapan pendahuluan), Transaction phase (tahapan pelaksanaan), dan Outcomes phase (tahapan hasil). Kemudian diilustrasikan dalam model evaluasi stake countenance, dinyatakan bahwa ratarata siswa dapat mengidentifikasi sebab kehalalharaman makanan dan minuman.

3. Hasil belajar mata pelajaran fikih di MTsN 7 Kepung Kediri berupa (a) Siswa dapat memahami hukum pokok Islam secara terperinci khususnya jenis makanan dan minuman yang halal dan haram. (b) Dapat mengidentifikasi nilai-nilai yang ada dalam hukum Islam seperti nilai spiritual dan keterampilan; (c) Terbentuknya motivasi belajar yang kuat; (d) Memiliki pribadi yang bertanggung jawab, toleransi, dan disiplin; (e) Tumbuhnya sifat jujur, santun, dan percaya diri.

\section{Daftar Pustaka}

Bogdan and S. Biklen. Qualitatif Research for Education. Boston: Allyn And Bacon, 1992.

Budiarti, Erni, Zidni Zidni, and Bambang Eka Saputra. "Pengaruh Model Pembelajaran Kontekstual Terhadap Hasil Belajar Sejarah Siswa Kelas X MA NW Lenek Lauq." Fajar Historia: Jurnal Ilmu Sejarah Dan Pendidikan 2, no. 2 (December 6, 2018): 142-54.

Edgar, Andrew and Sedgwick, Peter. Key Concept in Cultural Theory. London and New York: Routlrdge, n.d.

Fuad, A. Jauhar. "Method of Discussion and Learning Styles towards Student's Critical Thinking Ability." Jurnal Penelitian Ilmu Pendidikan 13, no. 1 (June 8, 2020): 1-9. https://doi.org/10.21831/jpipfip.v13i1 .23592 . 
Hasnidar, Hasnidar. "Pengaruh Pembelajaran Kontekstual Terhadap Hasil Belajar Pkn Siswa Kelas Viii Smp Negeri 1 Ulaweng Kabupaten Bone." Edumaspul - Jurnal Pendidikan 1 (February 28, 2018): 42-47. https://doi.org/10.33487/edumaspul.v 1i1.39.

Ibrahim, Henra. "Implementasi Strategi Pembelajaran Kontekstual Dalam Pembentukan Karakter Peserta Didik Di Smp Negeri 2 Pinrang." Al-Ishlah: Jurnal Pendidikan Islam 16, no. 1 (June 20, 2018): 74. https://doi.org/10.35905/alishlah.v16i 1.735 .

Koto, Alaidin. Ilmu Fikih Dan Ushul Fikih (Sebuah Pengantar). Jakarta: PT Rajagrafindo Persada, 2009.

Lexy J. Moleong. Metodologi Penelitian Kualitatif. Bandung: PT Remaja Rosdakarya, 2000.

Sarwono, Sarlito W. Psikologi Remaja. Jakarta: PT. Rajagrafindo Persada, 2010 .

Suryani,Nunuk and Agung,Leo. Strategi Belajar - Mengajar. Yogyakarta: Ombak, 2012.

Taniredja,Tukiran dkk. Model-Model Pembelajaran Inovatif. Bandung: Alfabeta, 2011. 